\title{
Device Hematologic Problem Identified
}

National Cancer Institute

\section{Source}

National Cancer Institute. Device Hematologic Problem Identified. NCI Thesaurus. Code C92060.

The device affects or impacts the blood or its components. (See ISO 10993 all parts) 